\title{
The effectiveness of mindfulness-based programs on physical symptoms and psychological distress in patients with fibromyalgia: A systematic review
}

\author{
Miriam Henke · Anna Chur-Hansen
}

\begin{abstract}
Objective: Research into and the clinical use of mindfulness as a therapeutic intervention have increased in recent years and the results have been promising in a range of illness populations. One area in which mindfulness has been trialled is fibromyalgia, a chronic pain condition currently with poor treatment outcomes. The aim of this systematic review was to examine the effectiveness of mindfulness-based interventions on physical symptoms and psychological distress in patients with fibromyalgia. Methods: Systematic review: PubMed, PsycINFO, Embase and Scopus were searched for randomised controlled trials and prospective and retrospective studies. A quality assessment and synthesis of the quantitative data (based on guidelines from the Joanna Briggs Institute) was completed on studies using a mindfulness-based intervention with patients with fibromyalgia on outcomes related to physical symptoms and psychological distress and wellbeing. Results: Ten studies met the inclusion criteria. All included studies used a mindfulness-based group program design. Although outcome measures and data presentation varied, making statistical pooling impossible, the narrative synthesis resulted in overall positive evidence for the efficacy of mindfulness-based interventions for patients with fibromyalgia on a range of physical symptom and psychological distress outcome measures. Conclusion: Mindfulness is a favourable treatment option for patients with fibromyalgia. Whilst demonstrated efficacy was generally positive, the number of studies addressing this topic is small and there was wide variation in outcome measures and data presentation. More research is needed, particularly large-scale randomised controlled trials with consistent methodology, outcome measures and sufficient follow-up time periods.
\end{abstract}

Keywords: mindfulness meditation, fibromyalgia, Mindfulness-Based Stress Reduction, systematic review, mind-body therapies

\section{Introduction}

Fibromyalgia is a chronic pain condition that is not fully understood and often misdiagnosed [1]. Symptoms include chronic pain, fatigue, sleep disturbances, somatic symptoms, psychological distress and morning stiffness [2,3]. Diagnosis is based on a combination of patient history, physical examination, laboratory evaluations, and exclusion of other conditions $[4,5]$. The majority of patients with fibromyalgia are women in midlife, and the prevalence increases with age [6]. Symptoms are exacerbated by stress [7].

The organic aetiology of fibromyalgia remains unclear, and thus it is a challenging disorder to diagnose and treat [4]. Patients find fibromyalgia emotionally and psychologically distressing, 
and often report encountering a lack of support within health care systems [8]. Additionally, many patients do not expect conventional medical treatments to be effective [6].

Currently, conventional medical management does not lead to a cure [9]. Most pharmacological treatments aim to manage discrete symptoms, rather than the condition and its effects as a whole [10]. Goals of treatment are generally to control pain, increase functioning, facilitate adjustment and improve the wellbeing of patients [4]. Multi-disciplinary approaches, using both pharmacological and non-pharmacological interventions are recommended as best practice in the treatment of fibromyalgia [4]. Mind-body therapies (MBT) are an example of psychological treatments that have been found to be clinically effective in various health-related settings, and they are often equally as effective as pharmacological interventions [11]. Studies have indicated moderate to strong efficacy for MBT for a range of illnesses, including fibromyalgia. It has been suggested that MBT-orientated treatment could generate stable and permanent changes that enable patients to experience a significant improvement in their fibromyalgia symptoms [12].

MBT interventions refer to therapies that underscore the fundamental links between cognitions, emotion and physical health. Such interventions that have demonstrated effectiveness with a range of fibromyalgia symptoms include guided imagery [13], cognitive behaviour therapy (stand alone and also combined with hypnosis) [14], affective self-awareness (ASA) [15], meditation [16], and mindfulness [17]. Mindfulness meditation has been theoretically and empirically associated with psychological wellbeing, and recently has gained momentum as an accepted form of 'third wave' psychotherapy [18]. Higher degrees of mindfulness in patients with chronic pain are related to lower self-reported pain, reduced emotional distress, decreased disability, and less use of pain medication [19].

An intervention developed for people with chronic pain, based on mindfulness, is the Mindfulness-Based Stress Reduction (MBSR) model [20]. Given chronic pain is the central, and often most pervasive, symptom of fibromyalgia, a number of studies have investigated the effectiveness of mindfulness-based interventions such as MBSR. The MBSR program, developed by Kabat-Zinn and colleagues at the University of Massachusetts Stress Reduction Clinic, was designed to teach patients how to cope effectively with chronic medical conditions, reduce suffering by developing equanimity in the mind and body, and reduce stress and psychological distress [20].

It has been demonstrated that mindfulness interventions produce positive results, in particular for symptoms associated with fibromyalgia [21]. Sleep, for example, has been shown to be important in the management of fibromyalgia symptoms [22]. Mindfulness-based interventions have been shown to improve sleep and decrease sleep-interfering cognitive processes (e.g. rumination, worry), as concluded in a systematic review [23]. Some researchers, however, remain unconvinced of the efficacy of mindfulness interventions for fibromyalgia $[17,24]$ because of the weak methodologies characterising some research, including small sample sizes, uncontrolled variables and a lack of standardized interventions.

\subsection{Systematic review}

The aim of this systematic review was to explore the existing international literature [25] in order to assess the evidence for the effectiveness of mindfulness-based interventions on the subjective experience of physical symptoms and psychological distress outcomes in patient populations with fibromyalgia.

Reporting of this systematic review follows PRISMA [26] and Joanna Briggs Institute (JBI) guidelines [27]. 


\section{Method}

\subsection{Data sources and search strategy}

Any experimental study design including randomised controlled trials, non-randomised controlled trials, quasi-experimental or prospective or retrospective cohort studies, published in English, was included for review. Inclusion criteria were: a confirmed diagnosis of fibromyalgia, with no restriction on how the diagnosis was confirmed; outcome measures related to physical symptoms and/or psychological distress; separating reporting for patients with fibromyalgia where studies included heterogeneous samples; and sufficient information on the effectiveness of a mindfulness-based intervention, expressed as effect sizes, or mean differences.

The search strategy aimed to locate both published and unpublished studies. A three-step search was utilised. An initial limited search of PUBMED and PsycINFO was undertaken to identify potential keywords, followed by analysis of the text words contained in the title and abstract, and of the index terms used to describe the article. A second search using all identified keywords and index terms was then undertaken across all included databases. Thirdly, the reference lists of all identified reports and articles were searched for additional studies. Search terms are listed in Table 1.

Table 1. Search strategy terms by database

\begin{tabular}{|c|c|c|c|}
\hline PubMed & PsycINFO & Embase & Scopus \\
\hline Meditation [mh:noexp] OR & DE Mindfulness OR & \multirow{27}{*}{$\begin{array}{l}\text { Mindfulness } \\
\text { AND } \\
\text { Fibromyalgia } \\
\text { (mapping option } \\
\text { not selected) }\end{array}$} & Mindfulness \\
\hline Mindfulness [tiab] OR Mindfulness & DE Acceptance and & & AND \\
\hline Meditation [tiab] OR Mindfulness- & Commitment Therapy & & Fibromyalgia \\
\hline based [tiab] OR Mindfulness-based & OR DE Meditation OR & & NOT Yoga \\
\hline therap* [tiab] OR MBCT [tiab] NOT & DE Psychotherapeutic & & \\
\hline Yoga $[$ tiab] & Techniques OR & & \\
\hline AND & TI "mindfulness" OR & & \\
\hline Fibromyalgia* [mh:noexp] OR & $\mathrm{AB}$ "mindfulness" OR & & \\
\hline Syndrome, Fibromyalgia- & TI “mindful” OR AB & & \\
\hline Fibromyositis [tiab] OR & "mindful" OR TI & & \\
\hline Rheumatism, Muscular [tiab] OR & “acceptance and & & \\
\hline Muscular Rheumatism [tiab] OR & commitment*" OR AB & & \\
\hline Muscular Disorders [mh] OR & “acceptance and & & \\
\hline Fibrositis [tiab] OR Fibrositides & commitment ${ }^{* \prime \prime}$ OR TI & & \\
\hline [tiab] OR Myofascial Pain & "meditation" OR AB & & \\
\hline Syndrome, Diffuse [tiab] OR & “meditation" OR TI & & \\
\hline Diffuse Myofascial Pain Syndrome & "mindfulness-based" & & \\
\hline [tiab] OR Fibromyositis- & OR AB "mindfulness- & & \\
\hline Fibromyalgia Syndrome [tiab] OR & based" OR TI MBCT & & \\
\hline Fibromyositis-Fibromyalgia* [tiab] & OR AB MBCT NOT & & \\
\hline OR Syndrome, Fibromyositis- & “awareness” NOT & & \\
\hline Fibromyalgia [tiab] OR & “ACT” NOT “PZ & & \\
\hline Syndromes, Fibromyositis- & editorial" & & \\
\hline Fibromyalgia [tiab] OR Secondary & AND & & \\
\hline Fibromyalgia* $[$ tiab] & DE Fibromyalgia OR & & \\
\hline \multirow[t]{2}{*}{ OR Pain [mh] NOT chronic [tiab] } & TI "fibromyalgia" OR & & \\
\hline & $\mathrm{AB}$ "fibromyalgia & & \\
\hline
\end{tabular}


The search was performed in PubMed, PsycINFO, Embase and Scopus and focused on randomised controlled trials and prospective and retrospective studies. Each database was searched from its onset until May 2013. There were no publication date restrictions. Only articles written in English were included. Multiple keywords and medical subject headings (MESH terms) for mindfulness and fibromyalgia were combined.

\subsection{Study selection, critical appraisal, and risk of bias assessment}

The first author retrieved all relevant titles and abstracts $(\mathrm{N}=132)$. Full-text publications of studies that were potentially eligible for inclusion $(\mathrm{N}=21)$ were read and checked against the criteria for eligibility for inclusion in the review. Ten papers met the eligibility criteria and were included in the review.

The included studies were assessed according to a list of predefined criteria (MAStARI critical appraisal tool) as outlined in the JBI guidelines [27]. The list of criteria appears in the first column of Tables 2 and 3 below. Randomised controlled trials and cohort studies were separately evaluated with the appropriate criteria sets and a quality score produced (\%) for each individual study. A quality score was assigned to studies according to the degree to which they met the relevant criteria set: 'high quality' (low risk of bias, high confidence in estimate of effect) was indicated by a score of $70 \%$ or more; 'average quality' (moderate risk of bias, moderate confidence in estimate of effect) was indicated by a score of 50-69\%; and 'low quality' (high risk of bias, low confidence in estimate of effect) was indicated by a score of less than $50 \%$.

\subsection{Data extraction and analysis}

Data were extracted from included papers on study population, design, intervention, duration of follow-up, and measurement and outcomes of physical symptoms and/or psychological distress. A brief summary of the reported results from each study is included in the final column of Table 4 below. Studies were grouped into the categories based on their design (randomised controlled trial or cohort study). Quality of evidence, outcomes measured, reported results, study strengths and limitations are all discussed.

\section{Results}

The results of the search are shown in Figure 1 below. Five studies were randomised controlled trials [28,29,30,31,32], two were controlled cohort studies [33,34] and three were non-controlled cohort studies [35,36,37]. Characteristics of each study are outlined in Tables 2 and 3 below.

\subsection{Study characteristics}

Data of the quality assessment (based on JBI guidelines) of the included studies are provided in Table 2 (randomised controlled trials) and Table 3 (cohort studies) below.

The mean quality score was $70 \%$ (high quality), ranging from $33 \%$ to $100 \%$. Six studies had a high quality score (>70\%) [28-30,33,34,35], three studies had a moderate quality score $(50-69 \%)$ $[32,36,37]$, and one study had a low quality score $(<50 \%)[34]$.

The specific outcomes measured across studies were highly variable; both in type and the way they were measured. Outcomes of all studies assessed subjective experiences of the symptomology of fibromyalgia (e.g. pain, functioning) or psychological distress (e.g. depression, anxiety). All except one of the included studies used outcomes that relied on self-reporting by participants; the exception used a body scanner to record skin conductance levels. Intervention design was described in all studies. Selection bias was present in four studies $[33,34,36,37]$. 
Figure I. Flowchart of study selection

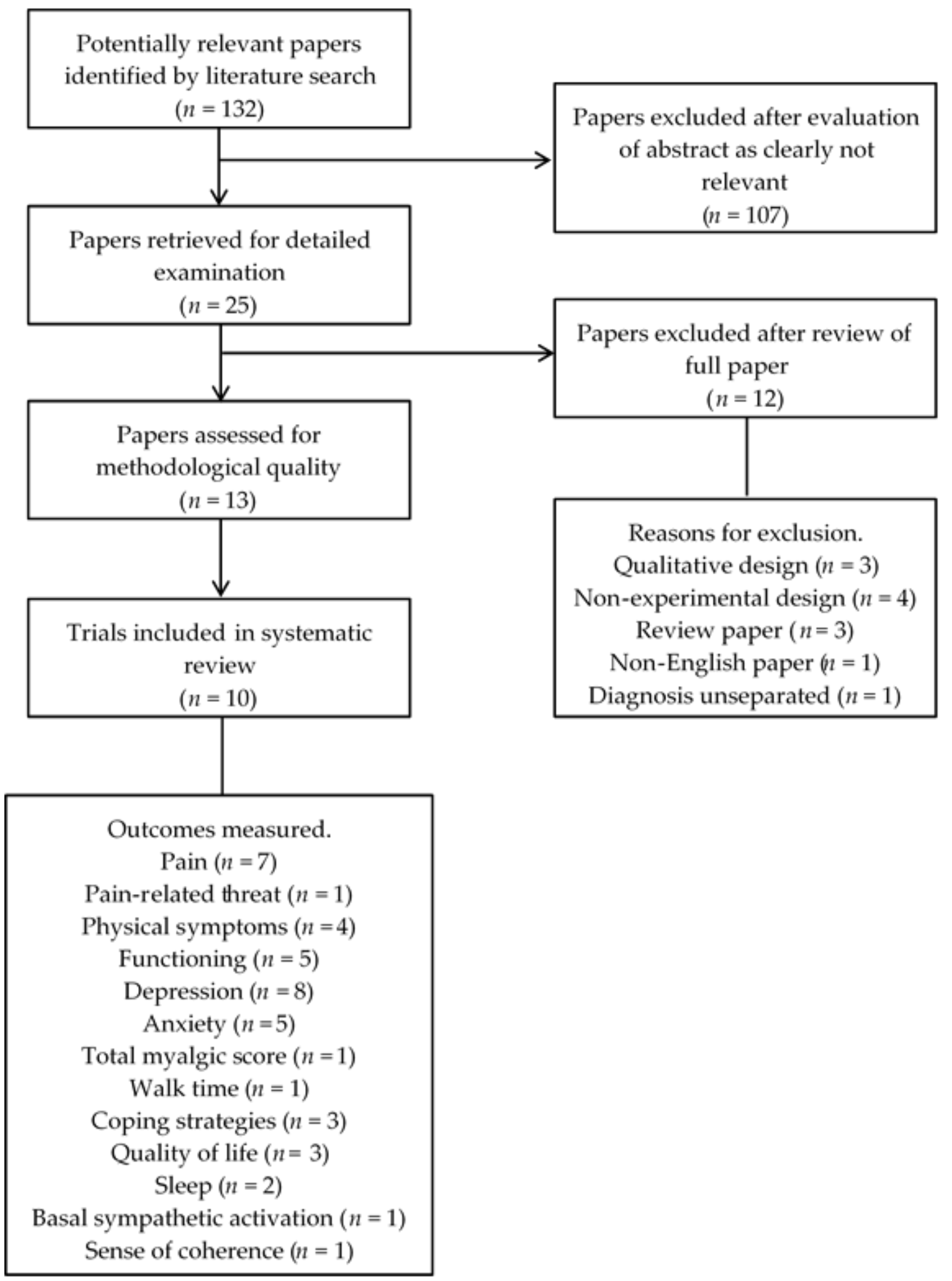


Table 2. Results of quality assessment for RCTs (Based on JBI MAStARI Checklist Criteria)

\begin{tabular}{|c|c|c|c|c|c|}
\hline \multirow[b]{2}{*}{ Criteria } & \multicolumn{5}{|c|}{ Study } \\
\hline & $\begin{array}{l}\text { Astin et } \\
\text { al. [28] }\end{array}$ & $\begin{array}{c}\text { Parra- } \\
\text { Delgado et } \\
\text { al. [29] }\end{array}$ & $\begin{array}{l}\text { Schmidt } \\
\text { et al. [30] }\end{array}$ & $\begin{array}{l}\text { Sephton et } \\
\text { al. [31] }\end{array}$ & $\begin{array}{c}\text { Weissbecker } \\
\text { et al. [32] }\end{array}$ \\
\hline $\begin{array}{l}\text { 1. Assignment to treatment group } \\
\text { truly random }\end{array}$ & + & + & + & + & + \\
\hline $\begin{array}{l}\text { 2. Participants blinded to } \\
\text { treatment allocation }\end{array}$ & $?$ & $?$ & + & + & - \\
\hline $\begin{array}{l}\text { 3. Allocation to treatment groups } \\
\text { concealed from allocator }\end{array}$ & $?$ & $?$ & + & $?$ & $?$ \\
\hline $\begin{array}{l}\text { 4. Outcomes of people who } \\
\text { withdrew described \& included } \\
\text { in analysis }\end{array}$ & + & + & + & + & + \\
\hline $\begin{array}{l}\text { 5. Researchers assessing } \\
\text { outcomes blind to treatment } \\
\text { allocation }\end{array}$ & + & $?$ & + & + & $?$ \\
\hline $\begin{array}{l}\text { 6. Control and treatment group } \\
\text { comparable at entry }\end{array}$ & + & + & + & + & + \\
\hline $\begin{array}{l}\text { 7. Groups treated identically } \\
\text { other than for named } \\
\text { interventions }\end{array}$ & + & + & + & - & - \\
\hline $\begin{array}{l}\text { 8. Outcomes measured in the } \\
\text { same way for all groups }\end{array}$ & + & + & + & + & + \\
\hline $\begin{array}{l}\text { 9. Outcomes measured in a } \\
\text { reliable way }\end{array}$ & + & + & + & + & + \\
\hline $\begin{array}{l}\text { 10. Appropriate statistical } \\
\text { analysis used }\end{array}$ & + & + & + & + & + \\
\hline Total Score per Study (\%) & $80 \%$ & $70 \%$ & $100 \%$ & $80 \%$ & $60 \%$ \\
\hline
\end{tabular}

All included studies used a mindfulness-based group program design. The outcome measures and data presentation varied too much to make statistical pooling possible. Therefore a narrative analysis (evidence synthesis) was completed to summarise the value of the prognostic indicators on common key outcome measures.

Three studies had interventions based on the MBSR program, with some variation from the protocol set by Kabat-Zinn et al. [20]. One study's intervention was delivered over 10 weeks rather than the usual 8 weeks [35]. One study incorporated Qigong, a Chinese movement therapy, into its intervention design [28]. One study used a mindfulness-based meditation training (MMT) intervention design (based on MBSR and Mindfulness-Based Cognitive Therapy), which the authors explained was designed to accommodate the physical limitations of the fibromyalgia population [34].

\subsection{Effectiveness on physical symptoms}

Seven studies reported on the effect of mindfulness on physical symptoms. Definition and measurement of physical symptoms across studies varied, and included pain, condition-specific symptoms, functionality, and sleep quality. Two studies reported an overall positive improvement in measures of physical symptoms in MBSR participants [33,35]. Two studies reported significant improvement in measures of physical symptoms for MBSR participants but 
demonstrated no significant between-group differences with the active controls [28,30]. Two studies reported no significant change in measures of physical symptoms in MBSR participants $[32,37]$.

Table 3. Results of quality assessment for Cohort studies (Based on JBI MAStARI Checklist Criteria)

\begin{tabular}{|c|c|c|c|c|c|}
\hline \multirow[b]{2}{*}{ Criteria } & \multicolumn{5}{|c|}{ Study } \\
\hline & $\begin{array}{c}\text { Grossman } \\
\text { et al. [33] }\end{array}$ & $\begin{array}{l}\text { Vago et al. } \\
\text { [34] }\end{array}$ & $\begin{array}{l}\text { Kaplan et } \\
\text { al. [35] }\end{array}$ & $\begin{array}{l}\text { Lush et al. } \\
\text { [36] }\end{array}$ & $\begin{array}{c}\text { Rozenzweig } \\
\text { et al. [37] }\end{array}$ \\
\hline $\begin{array}{l}\text { 1. Sample is representative of } \\
\text { patients in population as a } \\
\text { whole }\end{array}$ & - & 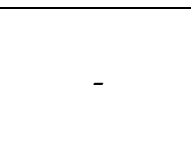 & + & - & $?$ \\
\hline $\begin{array}{l}\text { 2. Patients are at a similar } \\
\text { point in the course of their } \\
\text { condition/illness }\end{array}$ & + & $?$ & $?$ & $?$ & $?$ \\
\hline $\begin{array}{l}\text { 3. Bias minimised in relation } \\
\text { to selection of cases and } \\
\text { controls }\end{array}$ & + & - & + & $?$ & + \\
\hline $\begin{array}{l}\text { 4. Confounding factors } \\
\text { identified and strategies to } \\
\text { deal with them stated }\end{array}$ & + & ? & + & - & $?$ \\
\hline $\begin{array}{l}\text { 5. Outcomes assessed using } \\
\text { objective criteria }\end{array}$ & + & + & + & + & + \\
\hline $\begin{array}{l}\text { 6. Follow up carried out of a } \\
\text { sufficient time period }\end{array}$ & + & $?$ & + & + & + \\
\hline $\begin{array}{l}\text { 7. Outcomes of people who } \\
\text { withdrew described and } \\
\text { included in analysis }\end{array}$ & - & $?$ & - & + & + \\
\hline $\begin{array}{l}\text { 8. Outcomes measured in a } \\
\text { reliable way }\end{array}$ & + & + & + & + & + \\
\hline $\begin{array}{l}\text { 9. Appropriate statistical } \\
\text { analysis used }\end{array}$ & + & + & + & + & + \\
\hline Total Score per Study (\%) & $78 \%$ & $33 \%$ & $78 \%$ & $56 \%$ & $67 \%$ \\
\hline
\end{tabular}

Six studies reported on the effect of mindfulness-based programs on pain-related measures. Of these six, four studies reported significant pre- to post-intervention improvement in pain-related scores. However, only one of these studies (with control group) reported significant betweengroup differences in favour of the MBSR intervention group [28]. For the other three studies reporting positive changes, there were no significant between-group differences. Two studies $[29,36]$ reported no significant change in pain-related measures for the mindfulness-based intervention participants. Two studies measured and reported on pain-related coping (patient's perception of ability to control and decrease pain), both finding the MBSR intervention produced a positive or significant improvement in the treatment group [28,36].

Three studies $[28,30,35]$ measured and reported on sleep. One study reported positive clinically significant changes as higher for the MBSR group (17\%) as compared with the wait-list group (10\%) and the active control group (7\%) [30]. However, these results did not produce statistical significance in their comparison between-groups by analysis of covariance. One study reported that $60 \%$ of the patients with fibromyalgia who received the MBSR treatment 
experienced a positive (improvement) mean change of $2.6 \%$ [35]. One study reported the MBSR treatment group demonstrated significantly improved sleep at both the post-intervention and 3year follow up time points [33].

Five studies used the Fibromyalgia Impact Questionnaire (FIQ). The FIQ is a 10-item validated disease-specific scale that assesses physical functioning, pain, depression, anxiety, fatigue, morning tiredness, stiffness, job difficulty, and overall wellbeing. While two studies $[29,35]$ reported a positive mean percentage change, a high-quality RCT reported the MBSR intervention and active control groups both had a significant improvement on the FIQ [28]. Two RCTs reported no significant results with regard to FIQ scores when compared to Sense of Coherence (SOC) as a variable [32] or between-group differences [30].

\subsection{Effectiveness on psychological distress}

All ten studies assessed and reported on various measures of psychological distress. Four studies reported significant improvement in the mindfulness groups on all measures of psychological distress [28,29,33,35], which included depression, anxiety, psychological distress (specific), and perceived helplessness. One study reported that the MBSR program produced a significant decrease in avoidance, and increase in engagement and efficient disengagement from painrelated threat [34].

Three studies reported mixed findings related to psychological distress in MBSR intervention participants. One study reported that SOC significantly increased in the MBSR group compared to the wait-list control group, and that higher SOC was significantly correlated with lower levels of perceived stress and depression [32]. However, SOC did not buffer the effects of fibromyalgia symptoms on psychological distress in the treatment group. One study found that while the MBSR group had a range of significant pre- to post-treatment changes, there were no significant differences between groups for anxiety or depression [30]. One study reported significant effects of MBSR intervention for somatic symptoms but not cognitive symptoms [31]. Two studies reported non-significant results for the MBSR interventions on psychological distress [36,37].

Three studies reported on measured and reported quality of life (QoL) outcome measures. One study reported significantly greater benefits on QoL in the MBSR group compared with the active control group, including sustained benefits at the 3-year follow up [33]. One study reported modest significant pre- to post-treatment improvement for the MBSR group, with no significant differences between groups, with the whole cohort improving significantly on the health-related quality of life (HRQoL) measure [30]. One study reported that the small fibromyalgia sample in their MBSR cohort who completed the program experienced statistically significant improvement on three of eight HRQoL measures (mean $d=.49$ ), including general health perception, vitality, and mental health [37].

\subsection{Results summary}

Of the ten studies included in this systematic review, all claimed significant positive benefit, to some degree, of a mindfulness-based intervention for patients with fibromyalgia. While there was consistency in the design of the mindfulness-based interventions, the outcomes measured, sample sizes, and data presented varied extensively. Therefore, direct comparison of the studies is limited and reliable conclusions cannot be drawn. 
Table 4a. Characteristics of studies and main results

\begin{tabular}{|c|c|c|c|c|c|c|c|c|c|}
\hline $\begin{array}{l}\text { Study/ } \\
\text { Country }\end{array}$ & $\begin{array}{l}\text { Study } \\
\text { Quality }\end{array}$ & $\begin{array}{l}\text { Type of } \\
\text { Study }\end{array}$ & $\mathbf{N}$ & $\begin{array}{l}\text { Method of } \\
\text { Recruitment }\end{array}$ & Type of Intervention & $\begin{array}{l}\text { Comparison } \\
\text { Group }\end{array}$ & Outcome Measures & $\begin{array}{l}\text { Data } \\
\text { Measured }\end{array}$ & Description of Main Results \\
\hline $\begin{array}{l}\text { Astin et al. } \\
\text { [28] } \\
\text { United } \\
\text { States }\end{array}$ & $80 \%$ & $\begin{array}{l}\text { Experi- } \\
\text { mental } \\
\text { Random- } \\
\text { ised } \\
\text { Control } \\
\text { Trial }\end{array}$ & 128 & $\begin{array}{l}\text { - Radio/ } \\
\text { newspaper } \\
\text { advertising } \\
\text { - Networking } \\
\text { with local } \\
\text { physicians }\end{array}$ & $\begin{array}{l}\text { - Group-based } \\
\text { mindfulness-based } \\
\text { meditation training and } \\
\text { Qigong }(\mathrm{n}=64) \\
-2.5 \mathrm{~h} \text { per week for } 8 \\
\text { weeks } \\
\text { - No homework } \\
\text { requirements noted }\end{array}$ & $\begin{array}{l}\text { - Active } \\
\text { control }(\mathrm{n}= \\
64) \\
\text { - Education/ } \\
\text { Support } \\
\text { - } 2.5 \text { h per } \\
\text { week for } 8 \\
\text { weeks }\end{array}$ & $\begin{array}{l}\text { - Tender point count } \\
\text { - Total Myalgic Score } \\
\text { - Pain and Functioning } \\
\text { (FM Impact } \\
\text { Questionnaire) } \\
\text { - Pain (SF-36) } \\
\text { - } 6 \text { minute walk time } \\
\text { - Depression (BDI) } \\
\text { - Medical care history } \\
\text { - Coping Strategies } \\
\text { Questionnaire }\end{array}$ & $\begin{array}{l}\text { Baseline, } 8 . \\
16 \text { and } 24 \\
\text { weeks }\end{array}$ & $\begin{array}{l}\text { - Both treatment and active } \\
\text { control groups had } \\
\text { significant improvements on } \\
\text { FIQ, Total Myalgic Score, } \\
\text { Pain and Depression } \\
\text { - No difference in magnitude } \\
\text { of changes between groups } \\
\text { - Changes in both groups } \\
\text { maintained a } 6 \text { month follow } \\
\text { up }\end{array}$ \\
\hline $\begin{array}{l}\text { Parra- } \\
\text { Delgado et } \\
\text { al. [29] } \\
\quad \text { Spain }\end{array}$ & $70 \%$ & $\begin{array}{l}\text { Experi- } \\
\text { mental } \\
\text { Random- } \\
\text { ised } \\
\text { Control } \\
\text { Trial }\end{array}$ & 33 & $\begin{array}{l}\text { - Members of } \\
\text { the } \\
\text { Fibromyalgia } \\
\text { Association of } \\
\text { Almansa, } \\
\text { Spain }\end{array}$ & $\begin{array}{l}\text { - Group-based MBCT } \\
\text { program }(\mathrm{n}=17) \\
\text { - } 8 \times 2.5 \mathrm{~h} \text { sessions over } \\
3 \text { months } \\
\text { - Homework }\end{array}$ & $\begin{array}{l}\text { Treatment- } \\
\text { as-usual } \\
\text { control } \\
\text { group }(\mathrm{n}= \\
\text { 16) }\end{array}$ & $\begin{array}{l}\text { - Mini International } \\
\text { Neuropsychiatric } \\
\text { Interview (MINI) } \\
\text { - Fibromyalgia Impact } \\
\text { Questionnaire (FIQ) } \\
\text { - Beck Depression } \\
\text { Inventory (BDI) } \\
\text { - Visual Analogue Scale } \\
\text { (VAS) }\end{array}$ & $\begin{array}{l}\text { Baseline, } \\
\text { post- } \\
\text { treatment, } \\
\text { and } 3 \\
\text { months } \\
\text { post- } \\
\text { interven- } \\
\text { tion }\end{array}$ & $\begin{array}{l}\text { - MBCT significantly } \\
\text { improved both the impact of } \\
\text { fibromyalgia and depressive } \\
\text { symptoms at post-treatment } \\
\text { (FIQ } t=6.79, p<.001 \text {; BDI } t= \\
5.50, p<.001 \text { ) and } 3 \text { month } \\
\text { (FIQ } t=6.14, p<.001 \text {; BDI } t= \\
6.19, p<.001 \text { ) } \\
\text { - A slight, non-significant } \\
\text { decrease in intensity of pain } \\
\text { observed }\end{array}$ \\
\hline
\end{tabular}


Table $4 \mathrm{~b}$. Characteristics of studies and main results

\begin{tabular}{|c|c|c|c|c|c|c|c|c|c|}
\hline $\begin{array}{l}\text { Study/ } \\
\text { Country }\end{array}$ & $\begin{array}{l}\text { Study } \\
\text { Quality }\end{array}$ & $\begin{array}{l}\text { Type of } \\
\text { Study }\end{array}$ & $\mathbf{N}$ & $\begin{array}{l}\text { Method of } \\
\text { Recruitment }\end{array}$ & Type of Intervention & $\begin{array}{l}\text { Comparison } \\
\text { Group }\end{array}$ & Outcome Measures & $\begin{array}{l}\text { Data } \\
\text { Measured }\end{array}$ & Description of Main Results \\
\hline $\begin{array}{l}\text { Schmidt et } \\
\text { al. [30] } \\
\text { Germany }\end{array}$ & $100 \%$ & $\begin{array}{l}\text { Experi- } \\
\text { mental } \\
\text { Random- } \\
\text { ised } \\
\text { Control } \\
\text { Trial (3- } \\
\text { arm) }\end{array}$ & 177 & $\begin{array}{l}\text { - Patient self- } \\
\text { help groups } \\
\text { - News media } \\
\text { - Referrals from } \\
\text { general } \\
\text { practitioners, } \\
\text { rheumatologists, } \\
\text { and University } \\
\text { of Freiburg } \\
\text { Medical Center } \\
\text { Interdisciplinary } \\
\text { Pain Unit }\end{array}$ & $\begin{array}{l}\text { - Group-based MBSR } \\
\text { program }(\mathrm{n}=53) \\
\text { - } 2.5 \mathrm{~h} \text { per week for } 8 \\
\text { weeks } \\
\text { - Additional } 7 \mathrm{~h} \text { all- } \\
\text { day session on a } \\
\text { weekend day } \\
\text { - Homework of } 45-60 \\
\text { mins daily }\end{array}$ & $\begin{array}{l}2 \text { Control } \\
\text { Groups } \\
\text { (1) Active } \\
\text { Control ( } \mathrm{n}= \\
56) \text {. Control } \\
\text { for } \\
\text { nonspecific } \\
\text { aspects of } \\
\text { MBSR } \\
\text { curriculum; } \\
2.5 \text { h per } \\
\text { week for } 8 \\
\text { weeks } \\
\text { (Education/S } \\
\text { upport) } \\
\text { (2) Wait-list } \\
\text { Control (no } \\
\text { active } \\
\text { treatment) (n } \\
\text { = 59) }\end{array}$ & $\begin{array}{l}\text { - HRQoL (PLC) } \\
\text { - Pain and } \\
\text { Functioning (FIQ) } \\
\text { - Depression (CES-D) } \\
\text { - Anxiety (STAI) } \\
\text { - Quality of Sleep } \\
\text { (PSQI) } \\
\text { - Pain Perception } \\
\text { (PPS) } \\
\text { - Self-attribution of } \\
\text { mindfulness (FMI) } \\
\text { - Physical symptoms } \\
\text { (GCQ) } \\
\text { - Pre- and post- } \\
\text { intervention } \\
\text { interviews (personal } \\
\text { goals) }\end{array}$ & $\begin{array}{l}\text { Baseline, } 8 \\
\text { weeks and } \\
\text { short-term } \\
\text { follow-up }\end{array}$ & $\begin{array}{l}\text { - No significant difference } \\
\text { between groups on HRQoL, } \\
\text { patients overall improved at } \\
\text { short-term follow-up ( } p= \\
.004 \text { ) } \\
\text { - Post hoc and multivariate } \\
\text { analyses showed MBSR } \\
\text { group had a modest } \\
\text { significant pre-to-post } \\
\text { intervention improvement in } \\
\text { HRQoL ( } p=.02 \text { ) } \\
\text { - MBSR yielded significant } \\
\text { pre-to-post-intervention } \\
\text { improvements in } 6 \text { of } 8 \\
\text { secondary outcome } \\
\text { variables, the active control } \\
\text { in } 3, \text { and the wait list in } 2\end{array}$ \\
\hline
\end{tabular}


Table 4c. Characteristics of studies and main results

\begin{tabular}{|c|c|c|c|c|c|c|c|c|c|}
\hline $\begin{array}{l}\text { Study/ } \\
\text { Country }\end{array}$ & $\begin{array}{l}\text { Study } \\
\text { Quality }\end{array}$ & $\begin{array}{l}\text { Type of } \\
\text { Study }\end{array}$ & $\mathbf{N}$ & $\begin{array}{l}\text { Method of } \\
\text { Recruitment }\end{array}$ & Type of Intervention & $\begin{array}{l}\text { Comparison } \\
\text { Group }\end{array}$ & Outcome Measures & $\begin{array}{l}\text { Data } \\
\text { Measured }\end{array}$ & Description of Main Results \\
\hline $\begin{array}{l}\text { Sephton } \\
\text { et al. [31] } \\
\text { United } \\
\text { States }\end{array}$ & $80 \%$ & $\begin{array}{l}\text { Experi- } \\
\text { mental } \\
\text { Random- } \\
\text { ised } \\
\text { Control } \\
\text { Trial }\end{array}$ & 91 & $\begin{array}{l}\text { - Media } \\
\text { (television } \\
\text { broadcast and } \\
\text { newspaper) } \\
\text { advertisements }\end{array}$ & $\begin{array}{l}\text { - Group-based MBSR } \\
\text { program }(\mathrm{n}=51) \\
\text { - } 2.5 \mathrm{~h} \text { per week for } 8 \\
\text { weeks } \\
\text { - Home practice of } 30 \text { - } \\
45 \text { mins, } 6 \text { days per } \\
\text { week }\end{array}$ & $\begin{array}{l}\text { - Wait-list } \\
\text { control }(\mathrm{n}= \\
40) \\
\text { - First MBSR } \\
\text { session } \\
\text { attended by } \\
33 \text { of } 40 \\
\text { control } \\
\text { participants }\end{array}$ & $\begin{array}{l}\text { - Functional } \\
\text { impairment (FIQ) } \\
\text { - Pain (VAS) } \\
\text { - Sleep Quality (SSQ) } \\
\text { - Depressive } \\
\text { Symptoms (BDI) }\end{array}$ & $\begin{array}{l}\text { Baseline, } 8 \\
\text { weeks, and } 2 \\
\text { months post- } \\
\text { intervention }\end{array}$ & $\begin{array}{l}\text { - Depressive symptoms } \\
\text { improved significantly in } \\
\text { treatment versus control } \\
\text { participants } \\
\text { - Participants who still } \\
\text { meditated at end of study } \\
\text { had greatest reduction of } \\
\text { depressive symptoms } \\
(\mathrm{F}[1,30]=4.64, p=0.05) \\
\text { - Significant effects of } \\
\text { meditation practice were } \\
\text { found for somatic (F[1,30] = } \\
5.17, p=0.05) \text { but not } \\
\text { cognitive symptoms of } \\
\text { depression. }\end{array}$ \\
\hline $\begin{array}{l}\text { Weissbec } \\
\text { ker et al. } \\
{[32]}\end{array}$ & $60 \%$ & $\begin{array}{l}\text { Experi- } \\
\text { mental } \\
\text { Random- } \\
\text { ised }\end{array}$ & 91 & $\begin{array}{l}\text { - Local } \\
\text { television } \\
\text { morning news } \\
\text { broadcast }\end{array}$ & $\begin{array}{l}\text { - Group-based MBSR } \\
\text { program }(n=51) \\
\text { - } 2.5 \mathrm{~h} \text { per week for } 8 \\
\text { weeks }\end{array}$ & $\begin{array}{l}\text { Wait-list } \\
\text { control }(\mathrm{n}= \\
40)\end{array}$ & $\begin{array}{l}\text { - Sense of Coherence } \\
\text { (OLQ) } \\
\text { - Pain and } \\
\text { Functioning (FIQ) }\end{array}$ & $\begin{array}{l}\text { Baseline, } 8 \\
\text { weeks }\end{array}$ & $\begin{array}{l}\text { - Sense of Coherence (SOC) } \\
\text { was not a significant } \\
\text { moderator of symptom } \\
\text { effects on psychological }\end{array}$ \\
\hline $\begin{array}{l}\text { United } \\
\text { States }\end{array}$ & & $\begin{array}{l}\text { Control } \\
\text { Trial }\end{array}$ & & $\begin{array}{l}\text { - } 2 \text { newspaper } \\
\text { advertisements }\end{array}$ & $\begin{array}{l}\text { - Home practice daily } \\
\text { (6 days/week) }\end{array}$ & & $\begin{array}{l}\text { - Perceived } \\
\text { psychological stress - } \\
\text { (PSS) } \\
\text { - Depressive } \\
\text { symptoms (BDI) }\end{array}$ & & $\begin{array}{l}\text { distress } \\
\text { - MBSR group had } \\
\text { significant increase in SOC }(d \\
=139.54, S D=21.34) \text { post- } \\
\text { treatment, controls had } \\
\text { maintained stable SOC }(d= \\
130.08, S D=23.42) .\end{array}$ \\
\hline
\end{tabular}


Table 4d. Characteristics of studies and main results

\begin{tabular}{|c|c|c|c|c|c|c|c|c|c|}
\hline $\begin{array}{l}\text { Study/ } \\
\text { Country }\end{array}$ & $\begin{array}{l}\text { Study } \\
\text { Quality }\end{array}$ & $\begin{array}{l}\text { Type of } \\
\text { Study }\end{array}$ & $\mathbf{N}$ & $\begin{array}{l}\text { Method of } \\
\text { Recruitment }\end{array}$ & Type of Intervention & $\begin{array}{l}\text { Comparison } \\
\text { Group }\end{array}$ & Outcome Measures & $\begin{array}{l}\text { Data } \\
\text { Measured }\end{array}$ & Description of Main Results \\
\hline $\begin{array}{l}\text { Grossman } \\
\text { et al. [33] } \\
\text { Germany }\end{array}$ & $78 \%$ & $\begin{array}{l}\text { Quasi- } \\
\text { experi- } \\
\text { mental } \\
\text { Prospect- } \\
\text { ive } \\
\text { Cohort } \\
\text { (with } \\
\text { control) }\end{array}$ & 46 & $\begin{array}{l}\text { - Referral from } \\
\text { local physicians } \\
\text { - Fibromyalgia } \\
\text { self-help groups } \\
\text { in two cities }\end{array}$ & $\begin{array}{l}\text { - Group-based } \\
\text { Mindfulness-Based } \\
\text { Stress Reduction } \\
\text { (MBSR) program ( } \mathrm{n}= \\
\text { 39) } \\
\text { - } 2.5 \mathrm{~h} \text { per week for } 8 \\
\text { weeks plus all-day } \\
\text { retreat on weekend } \\
\text { day after } 5^{\text {th }} \text { week } \\
\text { - Homework for } 45 \\
\text { minutes per day }\end{array}$ & $\begin{array}{l}\text { - Active } \\
\text { control }(\mathrm{n}= \\
\text { 13) for } \\
\text { nonspecific } \\
\text { elements of } \\
\text { the MBSR } \\
\text { curriculum } \\
\text { - } 2.5 \mathrm{~h} \text { per } \\
\text { week for } 8 \\
\text { weeks }\end{array}$ & $\begin{array}{l}\text { - Quality of Life } \\
\text { (QoL) } \\
\text { - Hospital Anxiety \& } \\
\text { Depression Scale } \\
\text { (HADS, German } \\
\text { Version) } \\
\text { - Pain Perception } \\
\text { (PPS) } \\
\text { - Coping with } \\
\text { Chronic Pain (IPR) } \\
\text { - Physical symptoms } \\
\text { (SSI) }\end{array}$ & $\begin{array}{l}\text { Baseline, } 8 \\
\text { weeks, and } \\
\text { 3-year }\end{array}$ & $\begin{array}{l}\text { - MBSR intervention } \\
\text { provided significantly } \\
\text { greater benefits than control } \\
\text { intervention on VAS, QoL } \\
\text { subscales, coping with pain, } \\
\text { anxiety, depression and } \\
\text { somatic complaints (Cohen's } \\
\text { d effect size, } 0.40-1.10 \text { ) } \\
\text { - 3-year follow up of MBSR } \\
\text { participants indicated } \\
\text { sustained benefits on same } \\
\text { measures (effect size, } 0-50- \\
0.65 \text { ) }\end{array}$ \\
\hline $\begin{array}{l}\text { Vago et al. } \\
\text { [34] } \\
\text { United } \\
\text { States }\end{array}$ & $33 \%$ & $\begin{array}{l}\text { Quasi- } \\
\text { experi- } \\
\text { mental } \\
\text { Retro- } \\
\text { spective } \\
\text { Cohort } \\
\text { (with } \\
\text { control) }\end{array}$ & 24 & $\begin{array}{l}\text { - Recent } \\
\text { graduates of 8- } \\
\text { week MMT } \\
\text { program with } \\
\text { FM symptoms } \\
\text { were recruited } \\
\text { - Control } \\
\text { participants } \\
\text { recruited } \\
\text { independently } \\
\text { through } \\
\text { advertised flyer } \\
\text { investigating } \\
\text { cognitive and } \\
\text { emotional } \\
\text { processing in } \\
\text { FM }\end{array}$ & $\begin{array}{l}\text { - Group-based } \\
\text { Mindfulness-based } \\
\text { meditation training } \\
(\mathrm{MMT})(\mathrm{n}=13) \\
\text { - } 2.5 \mathrm{~h} \text { per week for } 8 \\
\text { weeks } \\
\text { - Home practice of } 30 \text { - } \\
45 \mathrm{~min} / \text { day }\end{array}$ & $\begin{array}{l}\text { Non-Active } \\
\text { Control }(\mathrm{n}= \\
11)\end{array}$ & $\begin{array}{l}\text { Pain-Related Threat - } \\
\text { Dot-probe task using } \\
\text { Eevoke software } \\
\text { stimulation package. } \\
\text { Measures reaction } \\
\text { times (RTs). Pain } \\
\text { words taken from } \\
\text { McGill Pain } \\
\text { Questionnaire. }\end{array}$ & $\begin{array}{l}\text { Post- } \\
\text { intervention, } \\
\text { and } 6 \\
\text { months }\end{array}$ & $\begin{array}{l}\text { - Preliminary results suggest } \\
\text { that MMT reduces avoidance } \\
\text { of pain-related threat at early } \\
\text { levels of processing, and } \\
\text { facilitates disengagement } \\
\text { from threat at later stages of } \\
\text { processing. }\end{array}$ \\
\hline
\end{tabular}


Table 4e. Characteristics of studies and main results

\begin{tabular}{|c|c|c|c|c|c|c|c|c|c|}
\hline $\begin{array}{l}\text { Study/ } \\
\text { Country }\end{array}$ & $\begin{array}{l}\text { Study } \\
\text { Quality }\end{array}$ & $\begin{array}{l}\text { Type of } \\
\text { Study }\end{array}$ & $\mathbf{N}$ & $\begin{array}{l}\text { Method of } \\
\text { Recruitment }\end{array}$ & Type of Intervention & $\begin{array}{l}\text { Comparison } \\
\text { Group }\end{array}$ & Outcome Measures & $\begin{array}{l}\text { Data } \\
\text { Measured }\end{array}$ & Description of Main Results \\
\hline $\begin{array}{l}\text { Kaplan et } \\
\text { al. [35] }\end{array}$ & $78 \%$ & $\begin{array}{l}\text { Experi- } \\
\text { mental } \\
\text { Prospective }\end{array}$ & 77 & $\begin{array}{l}\text { Diagnosed } \\
\text { patients of a } \\
\text { rheumatologist }\end{array}$ & $\begin{array}{l}\text { - Group-based MBSR } \\
\text { program }(n=77) \\
\text { - } 2 \text { h per week for } 10\end{array}$ & $\begin{array}{l}\text { No control } \\
\text { group }\end{array}$ & $\begin{array}{l}\text { - Visual Analog } \\
\text { Scales (VAS) } \\
\text { - Medical Symptom }\end{array}$ & $\begin{array}{l}\text { Baseline, and } \\
10 \text { weeks }\end{array}$ & $\begin{array}{l}\text { - Mean scores of all patients } \\
\text { completing MBSR program } \\
\text { showed improvement }\end{array}$ \\
\hline $\begin{array}{l}\text { United } \\
\text { States }\end{array}$ & & $\begin{array}{l}\text { Cohort (no } \\
\text { control) }\end{array}$ & & $\begin{array}{l}\text { were mailed a } \\
\text { letter outlining } \\
\text { program, asked } \\
\text { to respond by } \\
\text { phone or mail }\end{array}$ & $\begin{array}{l}\text { weeks } \\
\text { - Homework and 2x } \\
\text { day medications } \\
\text { included }\end{array}$ & & $\begin{array}{l}\text { Checklist (MSCL) } \\
\text { - General Severity } \\
\text { Index (SCL-90) } \\
\text { - Coping Strategies } \\
\text { Questionnaire (CSQ) } \\
\text { - Pain and } \\
\text { Functioning (FIQ) } \\
\text { - Fibromyalgia } \\
\text { Attitude Index (FAI) } \\
\text { - Overall Assessment } \\
\text { of Outcome } \\
\text { Questionnaire (OA) }\end{array}$ & & $\begin{array}{l}\text { - } 51 \% \text { showed moderate to } \\
\text { marked improvement } \\
\text { ("responders") } \\
\text { - } 90 \% \text { of participants considered } \\
\text { the MBSR program provided } \\
\text { them with valuable information } \\
\text { and was of some or significant } \\
\text { help in coping with } \\
\text { fibromyalgia }\end{array}$ \\
\hline $\begin{array}{l}\text { Lush et } \\
\text { al. [36] }\end{array}$ & $56 \%$ & $\begin{array}{l}\text { Experi- } \\
\text { mental } \\
\text { Prospective }\end{array}$ & 24 & $\begin{array}{l}\text { - Television } \\
\text { news } \\
\text { appearance by }\end{array}$ & $\begin{array}{l}\text { - Group-based MBSR } \\
\text { program }(n=24) \\
\text { - } 2.5 \text { h per week for } 8\end{array}$ & $\begin{array}{l}\text { No control } \\
\text { group }\end{array}$ & $\begin{array}{l}\text { - Brief Symptom } \\
\text { Inventory (BSI) } \\
\text { - Anxiety \& }\end{array}$ & $\begin{array}{l}\text { Baseline, and } \\
8 \text { weeks }\end{array}$ & $\begin{array}{l}\text { - MBSR treatment significantly } \\
\text { reduced basal electrodermal } \\
\text { activity }(t=3.298, p=.005) \text { and }\end{array}$ \\
\hline $\begin{array}{l}\text { United } \\
\text { States }\end{array}$ & & $\begin{array}{l}\text { Cohort (no } \\
\text { control) }\end{array}$ & & $\begin{array}{l}\text { investigators } \\
\text { one-year prior } \\
\text { to current study } \\
\text { - Radio \& } \\
\text { newspaper ads }\end{array}$ & $\begin{array}{l}\text { weeks } \\
\text { - Home practice of } 45 \\
\text { min, } 6 \text { days per week }\end{array}$ & & $\begin{array}{l}\text { Depressive symptoms } \\
\text { (BAI, BDI) } \\
\text { - Psychophysiological } \\
\text { recordings (SCL, HR, } \\
\text { and PT) using a J\&J I- } \\
330 \text { system }\end{array}$ & & $\begin{array}{l}\text { SCL activity during meditation } \\
(t=4.389, p=.001) \text {, consistent } \\
\text { with reduced basal sympathetic } \\
\text { (SNS) activation. }\end{array}$ \\
\hline $\begin{array}{l}\text { Rozenzw } \\
\text { eig et al. } \\
{[37]}\end{array}$ & $67 \%$ & $\begin{array}{l}\text { Experi- } \\
\text { mental } \\
\text { Prospective } \\
\text { Cohort (no }\end{array}$ & 11 & $\begin{array}{l}\text { - Part of larger } \\
\text { prospective } \\
\text { study }(\mathrm{n}=450) \\
\text { on MBSR from }\end{array}$ & $\begin{array}{l}\text { - Group-based MBSR } \\
\text { program }(n=11) \\
-2.5 \mathrm{~h} \text { per week for } 8 \\
\text { weeks }\end{array}$ & $\begin{array}{l}\text { No control } \\
\text { group }\end{array}$ & $\begin{array}{l}\text { - HRQoL (SF-36) } \\
\text { - Psychological } \\
\text { Distress (SCL-90-R) }\end{array}$ & $\begin{array}{l}\text { Baseline, and } \\
8 \text { weeks }\end{array}$ & $\begin{array}{l}\text { - Patients with fibromyalgia had } \\
\text { a small to medium reduction in } \\
\text { psychological distress (mean } d= \\
.39 \text { ) and experienced }\end{array}$ \\
\hline $\begin{array}{l}\text { United } \\
\text { States }\end{array}$ & & control) & & $\begin{array}{l}1997 \text { to } 2003 \\
\text { - Heterogeneous } \\
\text { sample of } \\
\text { chronic pain } \\
\text { patients }\end{array}$ & $\begin{array}{l}\text { - Homework of } 20-25 \\
\text { min formal } \\
\text { meditation daily, } 6 \\
\text { days per week }\end{array}$ & & & & $\begin{array}{l}\text { improvement on three of eight } \\
\text { HRQoL measures (mean } d=.49 \text { ), } \\
\text { including general health } \\
\text { perception, vitality and mental } \\
\text { health. }\end{array}$ \\
\hline
\end{tabular}




\section{Discussion}

\subsection{Main results}

Despite research that has been conducted in the area of mindfulness on chronic pain populations, this is the first systematic review of the literature that focuses on the effectiveness of mindfulness interventions on patients with fibromyalgia, regarding physical symptoms and psychological distress outcomes. Consistent with the previous literature, most of the results indicate improvement in fibromyalgia-related symptoms in patients who participated in a mindfulness-based intervention as compared with a control group.

Generally, the included studies were of moderate to high quality, with one exception. However, the heterogeneity between studies regarding numbers enrolled in the cohort, duration of follow-up, loss to follow-up, and outcome measures used is considerable. This limits direct comparability of the studies and makes it difficult to draw reliable conclusions about the efficacy of mindfulness-based interventions for fibromyalgia.

\subsection{Presence and impact of limitations of included studies}

There are a number of limitations applicable to the available studies as a whole, and others specific to individual studies. All included studies used a similar MBSR- or MBCT-based intervention, which is a strength in terms of intervention consistency. However, the commitment and energy requirements of these intervention programs are significant [30,36], and patients with fibromyalgia are often functionally impaired, with fatigue a common symptom. This leads to the conclusion that any significant results reported are generalisable only to patients without severe functional impairment, who have the interest, time and ability to participate in such meditation-based group interventions.

Nine of ten included studies included only women participants (and the other study had only one male participant in its MBSR group). While fibromyalgia is most common in women, the male to female incidence ratio is about 9:1 [38]; therefore the samples of each study are not truly generalisable to the population.

Across the board there was little attempt to separately evaluate the individual components of the mindfulness-based programs on the outcomes in any of the studies. This was of particular concern in the one study's intervention, which included a large Qigong component in the program design [28].

Small samples, high attrition rates, inconsistent follow-up periods, high loss to follow-up, and high use of subjective self-report measures were common limitations found in most of the studies. Finally, three of the included studies did not have control groups for direct comparison. These limitations are important to note, and pose a high risk of bias affecting the conclusions reached. Fortunately, consistent acknowledgement of study limitations by the authors avoided intervention effects being over estimated.

The randomised controlled trials using active control groups receiving comparable programs (controlling for the nonspecific effects of the mindfulness programs) [28,30] both found the control intervention provided some therapeutic benefit. Both studies found nonsignificant differences when comparing the mindfulness-based and active control groups. Thus the researchers were unable to conclude that mindfulness-based intervention was superior to the active control (education/support-based). 


\subsection{Directions for future research}

Ideally, to reach a definitive conclusion on the efficacy of mindfulness-based interventions for patients with fibromyalgia, consistent intervention designs, standardised measures and consistent follow-up measures are required. Given the variability found in the small number of available studies, a need for further research is evident. Such research requires carefully conceived and executed randomised controlled trials that take into account the necessity for both methodological stringency and specific condition-related needs. For example, one MBSR intervention should be tested using RCT methods across a range of participants with verified fibromyalgia, with Ns that allow for statistical power. Research of this nature requires longitudinal data collection.

\subsection{Conclusions and implications for clinical practice}

Mindfulness-based programs, as a mind-body therapy, may be a promising adjunctive treatment for a range of physical symptoms and psychological distress in patients with fibromyalgia. However, the findings of this systematic review are varied and inconclusive regarding the efficacy of mindfulness for fibromyalgia patients. The claimed positive results from the studies included in this review, however, are consistent with the stronger evidence on mindfulness in chronic pain and other illness population studies [39,40]. Whilst it is clear that mindfulness training can have positive psychological and physiologic effects, reliable conclusions cannot be reached at this time and further investigation is warranted.

\section{Authors}

Miriam Henke

School of Psychology, University of Adelaide

miriam@miriamhenke.com

Anna Chur-Hansen

School of Psychology, University of Adelaide

\section{Publishing Timeline}

Received 22 October 2013

Accepted 24 February 2014

Published 5 June 2014

\section{References}

[1] Wierwille L. Fibromyalgia: Diagnosing and managing a complex syndrome. Journal of the American Academy of Nurse Practitioners, 2012;24(4):184-92. http://dx.doi.org/10.1111/j.1745-7599.2011.00671.x

[2] Tausk R, Elenkov I, \& Moynihan J. Psychoneuroimmunology. Dermatologic Therapy. 2008;21:22-31. http://dx.doi.org/10.1111/j.1529-8019.2008.00166.x

[3] Martinez MP, Sanchez AI, Miro E, Medina A \& Lami MJ. The relationship between the fearavoidance model of pain and personality traits in fibromyalgia patients. Journal of Clinical Psychology in Medical Settings. 2011;18(4):380-91. http://dx.doi.org/10.1007/s10880-011-9263-2

[4] Peterson EL. Fibromyalgia - Management of a misunderstood disorder. Journal of the American Academy of Nurse Practitioners. 2007;19:341-8. http://dx.doi.org/10.1111/j.1745-7599.2007.00235.x 
[5] Wolfe F CD, Fitzcharles MA, Goldenberg DL, Katz RS, Mease P, et al. The American College of Rheumatology preliminary diagnostic criteria for fibromyalgia and measurement of symptom severity. Arthritis Care and Research. 2010;62:600-10. http://dx.doi.org/10.1002/acr.20140

[6] Sallinen M, Kukkurainen ML, Peltokallio L, Mikkelsson M, \& Anderberg UM. Fatigue, worry, and fear-Life events in the narratives of women with fibromyalgia. Health Care for Women International. 2012;33:473-94. http://dx.doi.org/10.1080/07399332.2011.645967

[7] Moriconi CB. A systemic treatment program of mindfulness meditation for fibromyalgia patients and their partners. Dissertation abstracts international B The Sciences and Engineering. 2004;64:5228.

[8] Daraz L. Information availability and needs of people living with fibromyalgia. Dissertation abstracts international B The Sciences and Engineering. 2012;72(8-b)

[9] Traska TK, Rutledge D, Mouttapa M, Weiss J, \& Aquino J. Strategies used for managing symptoms by women with fibromyalgia. Journal of Clinical Nursing. 2012;21:626-35. http://dx.doi.org/10.1111/j.1365-2702.2010.03501.x

[10] Lawson K. Treatment options and patient perspectives in the management of fibromyalgia: Future trends. Neuropsychiatric Disease and Treatment. 2008;4:1059-71. http://dx.doi.org/10.2147/NDT.S3468

[11] Pelletier KR. Mind as healer, mind as slayer: Mindbody medicine comes of age. Advances in Mind-body Medicine. 2002;18:4-15.

[12] Cuadros J, \& Vargas M. A new mind-body approach for a total healing of fibromyalgia: A case report. American Journal of Hypnosis. 2009;52:3-12. http://dx.doi.org/10.1080/00029157.2009.10401687

[13] Menzies C, \& Taylor A. The idea of imagination: an analysis of "imagery". Advances in Mind-body Medicine. 2004;20:4-10.

[14] Castel A. Multicomponent cognitive-behavioral group therapy with hypnosis for the treatment of fibromyalgia: Long-term outcome. The Journal of Pain. 2012;13:255-65. http://dx.doi.org/10.1016/j.jpain.2011.11.005

[15] Hsu MC, Schubiner H, Lumley MA, Stracks JS, Clauw DJ \& Williams DA. Sustained pain reduction through affective self-awareness in fibromyalgia: A randomized controlled trial. Journal of General Internal Medicine. 2010;25:1064-70. http://dx.doi.org/10.1007/s11606-010-1418-6

[16] Kozasa EH, Tanaka, L.H., Monson, C., Little, S., Leao, F.C. \& Peres, M.P. The effects of meditation-based interventions on the treatment of fibromyalgia. Current Pain and Headache Reports. 2012;16, 383-7. http://dx.doi.org/10.1007/s11916-012-0285-8

[17] Ebell M. How effective are complementary/alternative medicine (CAM) therapies for fibromyalgia? The Journal of Family Practice. 2001;50:400-1.

[18] Chiesa A \& Seretti A. Mindfulness-based interventions for chronic pain: a systematic review of the evidence. The Journal of Alternative and Complementary Medicine. 2011;17:83-93. http://dx.doi.org/10.1089/acm.2009.0546

[19] McCracken LM, Gauntlett-Gilbert J, \& Vowles KE. The role of mindfulness in a contextual cognitive-behavioral analysis of chronic pain-related suffering and disability. Pain. 2007;131:63-9. http://dx.doi.org/10.1016/j.pain.2006.12.013

[20] Kabat-Zinn J, Lipworth L, \& Burney R. The clinical use of mindfulness meditation for the self-regulation of chronic pain. Journal of Behavioral Medicine.1985;8:163-90. http://dx.doi.org/10.1007/BF00845519

[21] Young LA. Mindfulness meditation: A primer for rheumaologists. Rheumatic Diseases Clinics of North America. 2011;37:62-75. http://dx.doi.org/10.1016/j.rdc.2010.11.010 
[22] Miró E MM, Sanchez AI, Prados G, \& Medina A. When is pain related to emotional distress and daily functioning in fibromyalgia syndrome? The mediating roles of self-efficacy and sleep quality. British Journal of Health Psychology. 2011;16:799-814. http://dx.doi.org/10.1111/j.2044-8287.2011.02016.x

[23] Winbush NY, Gross CR, \& Kreitzer, MJ. The effects of mindfulness-based stress reduction on sleep disturbance: a systematic review. Explore (NY). 2007;3:585-91. http://dx.doi.org/10.1016/j.explore.2007.08.003

[24] Langhorst J, Hauser W, Bernardy K, Lucius H, Settan M, Winkelmann A, \& Musial F. Complementary and alternative therapies for fibromyalgia syndrome. Systematic review, meta-analysis and guideline. Schmerz. 2012;26:311-7. http://dx.doi.org/10.1007/s00482-012-1178-9

[25] The Campbell Collaboration. What is a systematic review? http://www.campbellcollaboration.org/what is a systematic review/index.html Accessed 5th March, 2014

[26] Moher D, Liberati A, Tetzlaff J, \& Altman DG. The PRISMA Group. Preferred reporting items for systematic reviews and meta-analyses: the PRISMA statement. Journal of Clinical Epidemiology. 2009;62;1006-12. http://dx.doi.org/10.1016/j.jclinepi.2009.06.005

[27] Joanna Briggs Institute. Joanna Briggs Institute reviewers' manual: 2011 edition. The Joanna Briggs Institute; 2011.

[28] Astin J, Berman BM, Bausell B, Lee W-L, Hochberg M \& Forys KL. Efficacy of mindfulness meditation plus qigong movement therapy in the treatment of fibromyalgia: A randomized controlled trial. Journal of Rheumatology. 2003;30:2257-62

[29] Parra-Delgado M, \& Latorre-Postigo JM. Effectiveness of mindfulness-based cognitive therapy in the treatment of fibromyalgia: A randomised trial. Cognitive Therapy and Research. 2013;37:1015-26. http://dx.doi.org/10.1007/s10608-013-9538-z

[30] Schmidt S, Grossman P, Schwarzer B, Jena S., Naumann J \& Walach H. Treating fibromyalgia with mindfulness-based stress reduction: Results from a 3-armed randomized controlled trial. Pain. 2011;152:361-9. http://dx.doi.org/10.1016/j.pain.2010.10.043

[31] Sephton SE, Salmon P, Weissbecker I, Ulmer C, Floyd A, Hoover K et al. Mindfulness meditation alleviates depressive symptoms in women with fibromyalgia: Results of a randomized clinical trial. Arthritis \& Rheumatism (Arthritis Care \& Research). 2007;57:77-85. http://dx.doi.org/10.1002/art.22478

[32] Weissbecker I, Salmon P, Studts JL, Floyd AR, Dedert EA \& Sephton SE. Mindfulness-based stress reduction and sense of coherence among women with fibromyalgia. Journal of Clinical Psychology in Medical Settings. 2002;9;297-307. http://dx.doi.org/10.1023/A:1020786917988

[33] Grossman P, Tiefenthaler-Gilmer U, Raysz A \& Kesper U. Mindfulness training as an intervention for fibromyalgia: Evidence of postintervention and 3-year follow-up benefits in well-being. Psychotherapy and Psychosomatics. 2007;76:226-33. http://dx.doi.org/10.1159/000101501

[34] Vago DR, \& Nakamura Y. Selective attentional bias towards pain-related threat in fibromyalgia: Preliminary evidence for effects of mindfulness meditation training. Cognitive Therapy and Research. 2011;35:581-94. http://dx.doi.org/10.1007/s10608-0119391-x

[35] Kaplan KH, Goldenberg DL \& Galvin-Nadeau M. The impact of a meditation-based stress reduction program on fibromyalgia. Annals of General Hospital Psychiatry. 1993;15:284-9. http://dx.doi.org/10.1016/0163-8343(93)90020-O

[36] Lush E, Salmon P, Floyd A, Studts JL, Weissbecker I, \& Sephton SE. Mindfulness meditation for symptom reduction in fibromyalgia: Psychophysiological correlates. Journal of Clinical Psychology in Medical Settings. 2009;16:200-7. http://dx.doi.org/10.1007/s10880-009-9153-z 
[37] Rosenzweig S, Greeson JM, Reibel DK, Green JS, Jasser SA \& Beasley D. Mindfulness-based stress reduction for chronic pain conditions: Variation in treatment outcomes and role of home meditation practice. Journal of Psychosomatic Research. 2010;68:29-36. http://dx.doi.org/10.1016/j.jpsychores.2009.03.010

[38] Bartels EM, Dreyer L, Jacobsen S, Jespersen A, Bliddal H \& Danneskoild-Samsoe B. Fibromyalgia, diagnosis and prevalence. Are gender differences explainable? Ugeskr Laeger. 2009;171;3588-92

[39] Robins CJ, Keng SL, Ekblad AG \& Brantley JG. Effects of mindfulness-based stress reduction on the emotional experience and expression: a randomized controlled trial. Journal of Clinical Psychology. 2012;68;117-131. http://dx.doi.org/10.1002/jclp.20857

[40] Day M, Thorn MA \& Burns JW. The continuing evolution of biopsychosocial interventions for chronic pain. Journal of Cognitive Psychotherapy. 2012;26;114-129. http://dx.doi.org/10.1891/0889-8391.26.2.114 